\title{
17. RELATIONSHIP BETWEEN GRAIN DENSITY AND BIOGENIC OPAL IN SEDIMENTS FROM SITES 658 AND $660^{1}$
}

\author{
Jürgen Mienert, ${ }^{2}$ Rüdiger Stein, ${ }^{3}$ Peter Schultheiss, ${ }^{4}$ and Shipboard Scientific Party ${ }^{5}$
}

\section{INTRODUCTION}

At Site 658 , and especially at Site 660 , sediments rich in biogenic opal were recovered. The fractions of biogenic silica, biogenic carbonate, and terrigenous material vary throughout the entire sequence at these sites (see chapters for Sites 658 and 660 , this volume).

At Site 660 , biogenic-opal contents up to $100 \%$ are common in Eocene sediments. In studying these opal-rich sediments, a rapid method for estimating biogenic opal published by Mann and Müller (1980) was found useful. These authors applied an $\mathrm{X}$-ray method which measures the height of a broad, diffuse reflection band of opal extending from about $15^{\circ}$ to $32^{\circ} 2 \theta$, with a maximum at about $22^{\circ} 2 \theta$ (i.e., $4.04 \AA$ ) (Fig. 1, IB).

Furthermore, this paper describes another method for estimating variations in the biogenic-opal content by using grain density. Grain density $(\rho)$ can easily be determined by measuring the weight $(G)$ and the volume $(V)$ of the dry sediment, where $\rho$ $=G / V\left(\mathrm{~g} / \mathrm{cm}^{3}\right)$.

\section{METHODS}

In this study the Mann and Müller (1980) method was slightly modified as follows. The absolute height of the background reflection $(h)$ at

\footnotetext{
${ }^{1}$ Ruddiman, W., Sarnthein, M., Baldauf, J., et al., 1987. Proc., Init. Repts. (Pt. A), ODP, 108 .

2 Geologisch-Paläontologisches Institut und Museum der Universität Kiel, Olshausenstrasse 40, D-2300 Kiel, Federal Republic of Germany, and Woods Hole Oceanographic Institution, Woods Hole, MA 02543.

3 Institut für Geowissenschaften und Lithosphärenforschung, Universität Giessen, Senckenbergstrasse 3, D-6300 Giessen, Federal Republic of Germany.

4 Institute of Oceanographic Sciences, Brook Road, Wormley, Godalming, Surrey GU8 5UG, United Kingdom.

5 William Ruddiman (Co-Chief Scientist), Lamont-Doherty Geological Observatory, Palisades, NY 10964; Michael Sarnthein (Co-Chief Scientist), Geologisch-Paläontologisches Institut, Universität Kiel, Olshausenstrasse 40, D-2300 Kiel, Federal Republic of Germany; Jack Baldauf, ODP Staff Scientist, Ocean Drilling Program, Texas A\&M University, College Station, TX 77843; Jan Backman, Department of Geology, University of Stockholm, S-106 91 Stockholm, Sweden; Jan Bloemendal, Graduate School of Oceanography, University of Rhode Island, Narragansett, RI 02882-1197; William Curry, Woods Hole Oceanographic Institution, Woods Hole, MA 02543; Paul Farrimond, School of Chemistry, University of Bristol, Cantocks Close, Bristol BS8 ITS, United Kingdom; Jean Claude Faugeres, Laboratoire de Géologie-Océanographie, Université de Bordeaux I, Avenue des Facultés, Talence 33405, France; Thomas Janacek, Lamont-Doherty Geological Observatory, Palisades, NY 10964; Yuzo Katsura, Institute of Geosciences, University of Tsukuba, Ibaraki 305, Japan; Hélène Manivit, Laboratoire de Stratigraphie des Continents et Océans, (UA 319) Université Paris VI, 4 Place Jussieu, 75230 Paris Cedex, France; James Mazzullo, Department of Geology, Texas A\&M University, College Station, TX 77843; Jürgen Mienert, Geologisch-Paläontologisches Institut, Universität Kiel, Olshausenstrasse 40, D-2300 Kiel, Federal Republic of Germany, and Woods Hole Oceanographic Institution, Woods Hole, MA 02543; Edward Pokras, Lamont-Doherty Geological Observatory, Palisades, NY 10964; Maureen Raymo, Lamont-Doherty Geological Observatory, Palisades, NY 10964; Peter Schultheiss, Institute of Oceanographic Sciences, Brook Road, Wormley, Godalming, Surrey GU8 SUG, United Kingdom; Rüdiger Stein, Geologisch-Paläontologisches Institut, Universität Giessen, Senckenbergstrasse 3, 6300 Giessen, Federal Republic of Germany; Lisa Tauxe, Scripps Institution of Oceanography, La Jolla, CA 92093; Jean-Pierre Valet, Centre des Faibles Radioactivités, CNRS, Avenue de la Terrasse, 91190 Gif-sur-Yvette, France; Philip Weaver, Institute of Oceanographic Sciences, Brook Road, Wormley, Godalming, Surrey GU8 5UG, United Kingdom; Hisato Yasuda, Department of Geology, Kochi University, Kochi 780 , Japan.
}

$22^{\circ} 2 \theta$ may also be influenced by other (clay) minerals such as montmorillonite and mixed layers (Fig. 1, III). Thus, the height $\left(h^{\prime}\right)$, instead of $h$ at $22^{\circ} 2 \theta$, was used as an improved measure of opal content. The height $\left(h^{\prime}\right)$ was determined by constructing line $A B C$, where $A$ is the point on the base line at $15^{\circ} 2 \theta, B$ the point on the X-ray-diffraction (XRD) diagram at about $19^{\circ} 2 \theta$, and $C$ a point at $22^{\circ} 2 \theta$ on a line extension of straight line $A B$ (defining the height, $h^{\prime}$ ). The line $A B C$ coincides with the base line if the opal content is less than $10 \%$ (Fig. 1, II and III). This implies that the Mann and Müller (1980) method may not be useful only if the biogenic-opal content has values greater than $10 \%$. Thus, for a more detailed investigation of biogenic opal in the Neogene sections at Sites 658 and 660, other methods may have to be used (e.g., Leinen, 1977; Koopmann, 1979; Bohrmann, 1986).

The calibration curve for estimating biogenic-opal content was determined by using mixtures of known biogenic-opal content. Because a pure biogenic-silica standard was not available on board JOIDES Resolution, Sample 108-660A-15H-4, 104-106 cm, was chosen as an endmember with $100 \%$ biogenic silica (Fig. 1, I). This assumption is based on (1) the XRD data, (2) the very low grain density of this sample, which is about $1.5 \mathrm{~g} / \mathrm{cm}^{3}$ (accuracy $\pm 0.02 \mathrm{~g} / \mathrm{cm}^{3}, 1.7-2.05 \mathrm{~g} / \mathrm{cm}^{3} \mathrm{den}-$ sity is typical for biogenic opal, Hurd and Theyer, 1977), and (3) optical determinations. Sample 108-658A-10H-1, 120-122 cm, was taken as the biogenic-opal-free end-member. In the X-ray diffractogram of this sample, no broad reflection band was recorded (Fig. 1, II). From both samples, standards of known biogenic-opal content were mixed. These standards, as well as all other samples, were measured by XRD using the following conditions: (1) generator settings, $40 \mathrm{kV}, 35 \mathrm{~mA}$; (2) step size, $0.020^{\circ}$; (3) count time, $1.00 \mathrm{~s}$; and (4) angle range $(2 \theta), 2.00^{\circ}$ to $40.00^{\circ}$.

The XRD diagrams of these measurements indicate the increasing height of the broad reflection band between $15^{\circ}$ and $33^{\circ} 2 \theta$ with increasing content of biogenic opal (Fig. 2). The resulting calibration curve is shown in Figure 3 as a plot of percentages of biogenic opal vs. height $\left(h^{\prime}\right)$ of the reflection band.

For the grain-density method the samples were dried for $8 \mathrm{hr}$ in the freeze drier and an additional $8 \mathrm{hr}$ in the oven at $110^{\circ} \mathrm{C}$. Afterward they were weighed on a motion-compensated Scitech electronic balance. The accuracy of the measurements is $\pm 0.02 \mathrm{~g}$, which was determined from 10 measurements of a calibration weight of $20 \mathrm{~g}$. Immediately after a sample was weighed, its volume was measured with a pycnometer. This method uses helium gas inserted into a defined volume, in which the difference between the empty cell and the cell containing the sediment determines the volume of the sediment sample. From volume and weight measurements, we calculate grain-density values. The estimated accuracy is about $\pm 0.02 \mathrm{~g} / \mathrm{cm}^{3}$.

Changes in grain density mainly reflect changes in the content of biogenic silica, biogenic carbonate, and terrigenous material. Because biogenic silica has a significantly lower grain density than other sedimentary components ( 1.7 to $2.05 \mathrm{~g} / \mathrm{cm}^{3}$; Hurd and Theyer, 1977; Mayer, 1979), and both biogenic carbonate and terrigenous material have a similar high density of about 2.6 to $2.75 \mathrm{~g} / \mathrm{cm}^{3}$, changes in grain density of the total sample can be used as a rough estimate of changes in biogenicopal content.

Clay minerals such as montmorillonite also may contribute significantly to lower grain-density values. However, according to the XRD data (e.g., Fig. 1), the relatively low amount of montmorillonite is assumed to have only minor influence on large-scale grain-density variations.

\section{RESULTS AND DISCUSSION}

Based on the calibration curve shown in Figure 3, most of the samples from Site 658 have biogenic-opal contents of less than $10 \%$ (Fig. 4A). By using a sample interval of $1.5 \mathrm{~m}, 7$ upper Pliocene and 2 middle Pleistocene samples are characterized 

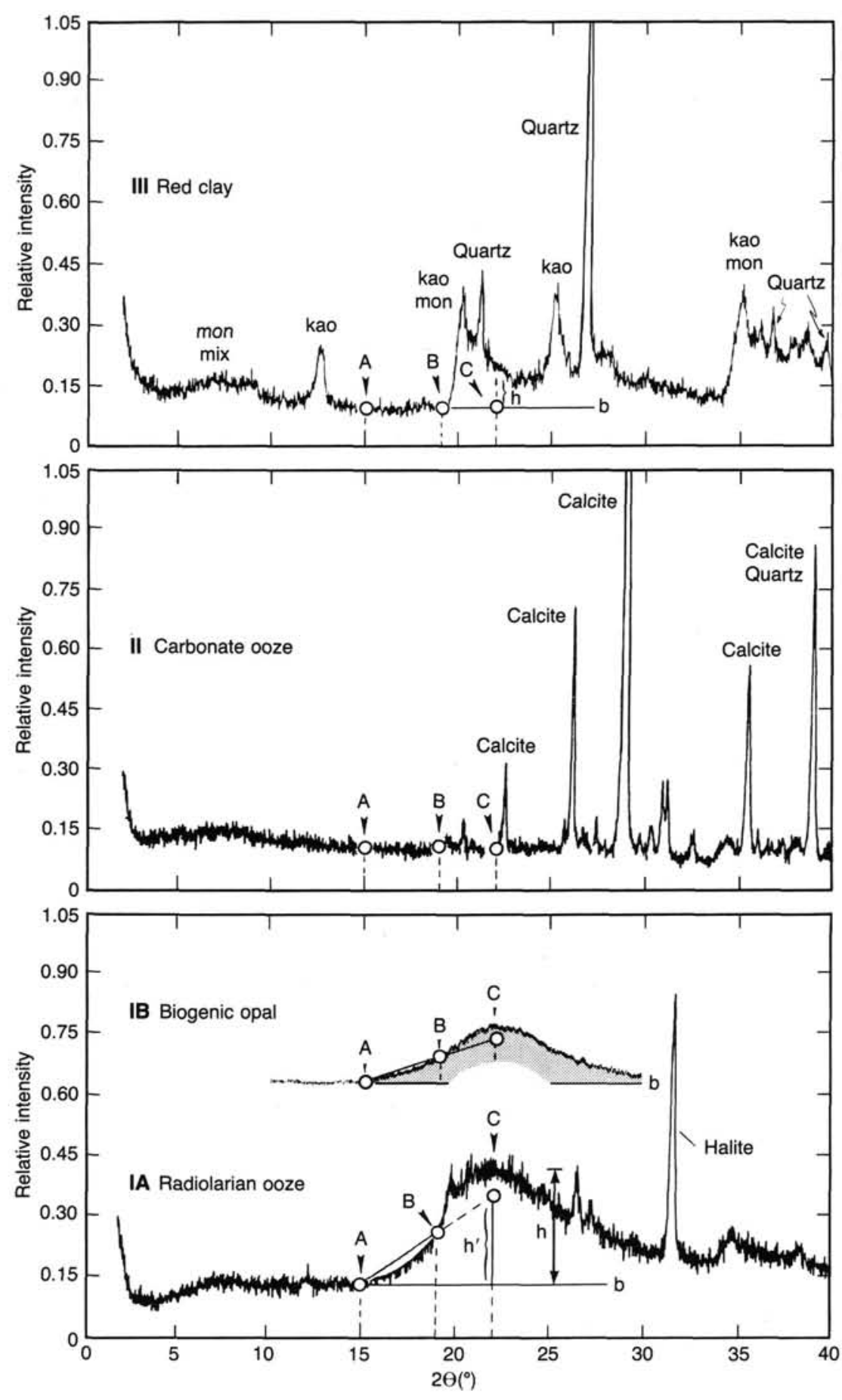

Figure 1. X-ray diffractograms of bulk sediment samples. IA. Sample 108-660A-15H-4, 104$106 \mathrm{~cm}$, which is assumed to consist of about $100 \%$ biogenic opal. IB. Biogenic opal from an opal mine in Australia (Bulla Creek, Queensland; Mann and Müller, 1980). II. Sample 108$658 \mathrm{~A}-10 \mathrm{H}-1,120-122 \mathrm{~cm}$, which contains no opal. III. Section 108-660A-11H, CC, which also contains no opal but does contain clay minerals such as montmorillonite (mon) and kaolinite (kao). The height, $h^{\prime}$, of the reflection band was measured at $22^{\circ} 2 \theta$ (point $C$ ) in centimeters above the base line, $b$. See text for further explanations.

by distinctly higher opal values of $10 \%$ to $50 \%$ (Fig. 4A). These peaks correlate with low grain-density values of 2.2 to $2.4 \mathrm{~g} / \mathrm{cm}^{3}$ and low carbonate values of $15 \%$ to $25 \%$ (Fig. $4 \mathrm{~B}$ and $4 \mathrm{C}$ ).

In contrast, the older samples from the upper and lower Pliocene (i.e., between 230 and $300 \mathrm{~m}$ below the seafloor, mbsf) also have low carbonate values of about $10 \%$ to $20 \%$ but high grain-density values of 2.5 to $2.85 \mathrm{~g} / \mathrm{cm}^{3}$ (Fig. $4 \mathrm{~B}$ and $4 \mathrm{C}$ ) and thus reflect a high siliciclastic component.

At Site 660 the Pliocene-Pleistocene interval is characterized by low biogenic-opal contents, except for one middle Pleisto- 


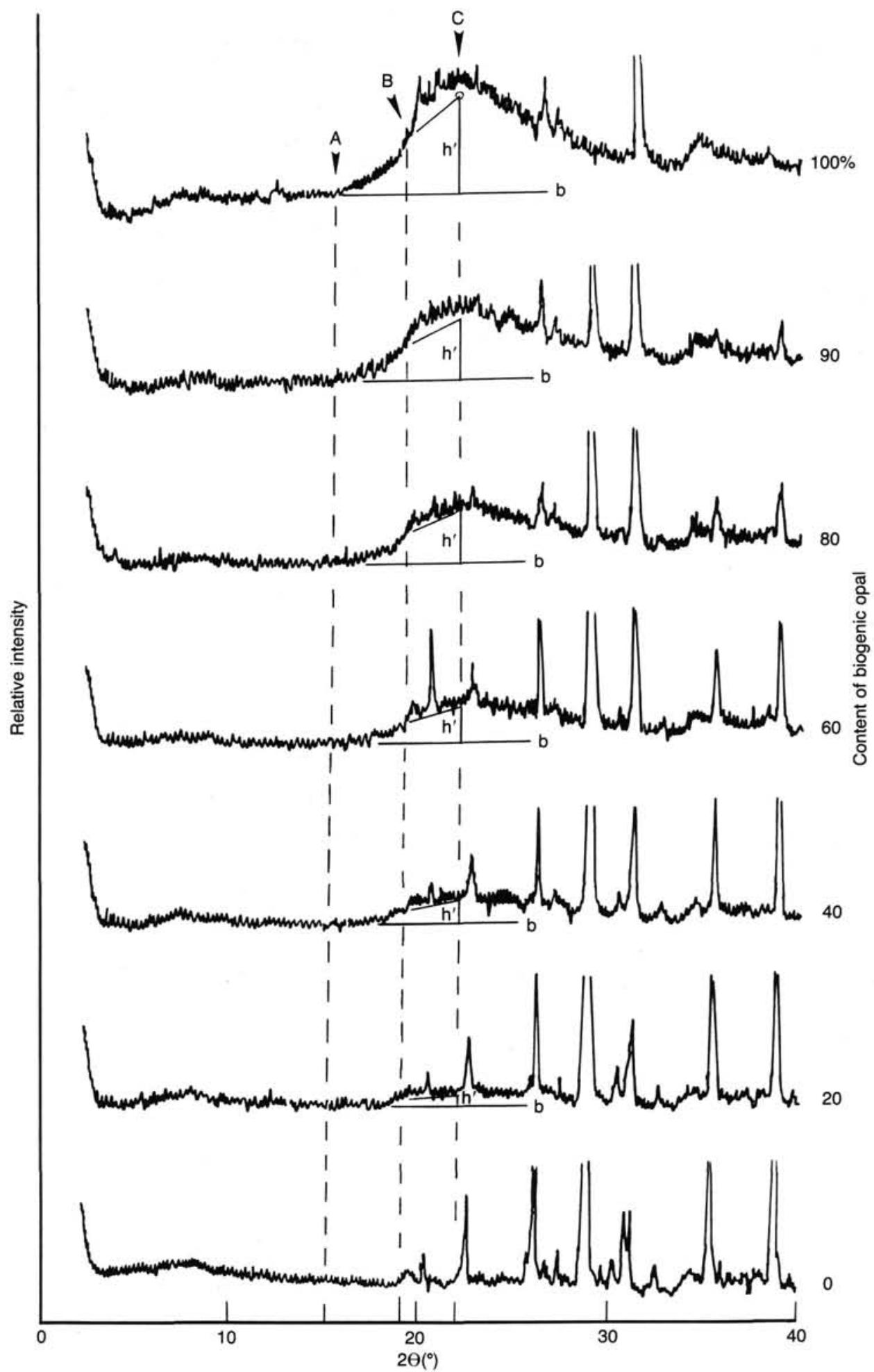

Figure 2. Diffractograms of mixtures of standards, showing increasing height of the reflection band above the base line with increasing biogenic-opal content.

cene sample with an opal content of about $20 \%$ (Fig. 5A). A similar event of biogenic-opal enrichment was also recorded at Site 658 from middle Pleistocene sediment.

In contrast to this event, the biogenic opal reaches values up to $100 \%$ in middle Eocene radiolarian ooze (30\% to $100 \%$, Fig.
5A). During that time, Site 660 lay underneath the equator (cf. Sclater et al., 1977); that is, it was influenced by equatorial upwelling. Thus, high oceanic productivity may have resulted in deposition of biogenic-opal-rich sediments in this area. Since then, Site 660 has drifted northward out of the high-productiv- 


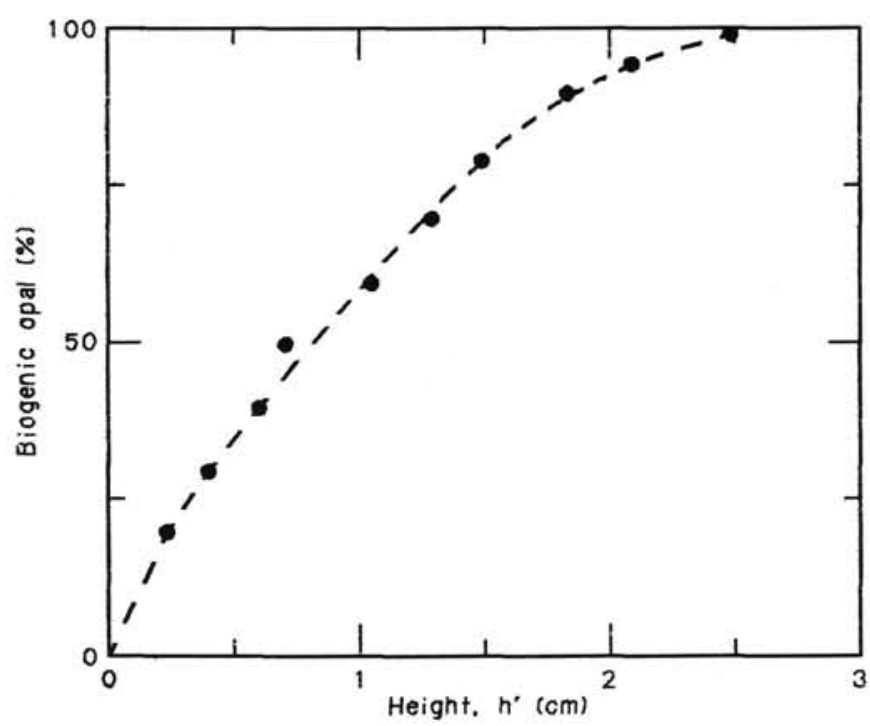

Figure 3. Calibration curve plotted as percentages of biogenic opal vs. height, $h^{\prime}$, of the reflection band above the base line at $22^{\circ} 2 \theta$.

ity belt. A similar evolution of depositional environments also was recorded at Sierra Leone Rise, at DSDP Site 366 (Stein, 1985) and at Site 667 (Site 667 chapter, this volume).

The accumulation of almost pure (and moderately well-sorted) radiolarian ooze at Site 660 may require further processes, such as bottom-current activity, to explain the extreme enrichment of radiolarians (Site 660 chapter, this volume). The samples with high biogenic-opal contents correlate with low grain-density values ranging from 1.5 to $2.2 \mathrm{~g} / \mathrm{cm}^{3}$ and low carbonate values ranging from $0 \%$ to $36 \%$ (Fig. 5). A distinct peak of very high grain density of $3.21 \mathrm{~g} / \mathrm{cm}^{3}$ occurs at $126 \mathrm{mbsf}$, possibly caused by significant amounts of manganite (Site 660 chapter, this volume).

In general, samples with grain-density values of 1.4 to $2.4 \mathrm{~g}$ / $\mathrm{cm}^{3}$ are characterized by high biogenic-opal contents of $10 \%$ to $100 \%$ (Fig. 6). Because quartz and carbonate sediments have densities between 2.65 and $2.75 \mathrm{~g} / \mathrm{cm}^{3}$, samples characterized by biogenic-opal contents of less than $10 \%$ and relatively low grain densities of about 2.4 to $2.65 \mathrm{~g} / \mathrm{cm}^{3}$ (Fig. 6) must contain additional components with distinctly lower grain-density values, such as montmorillonite.

\section{SUMMARY AND CONCLUSIONS}

Biogenic-opal content determined by a slightly modified Mann and Müller method (1980) shows large-scale variations in bio- genic opal between $0 \%$ and $100 \%$. Three major events of biogenic-opal deposition were recorded: (1) middle Eocene at Site 660 , (2) late Pliocene at Site 658, and (3) middle Pleistocene at Sites 658 and 660 . However, changes in opal content in the range of $0 \%$ to $10 \%$ cannot be resolved by this method.

If changes in the content of montmorillonite are of minor importance, the compilation of grain-density and carbonatecontent records allows us to distinguish between intervals of relatively increased supply of terrigenous matter and intervals of relatively increased input of biogenic opal. Such records can help to reconstruct the history of climate-controlled sedimentation and the paleoenvironment.

\section{ACKNOWLEDGMENTS}

We gratefully thank ODP technicians Peggy Myre, Katie Sigler, Mark Dobday, Matt Mefferd, and Christian Segade for their help in processing the enormous amount of data for this study. This paper was reviewed by J. Baldauf, W. Ruddiman, M. Sarnthein, G. Jones, W. B. Curry, and K. Takahashi. This is Woods Hole Contribution No. 6513 .

\section{REFERENCES}

Bohrmann, G., 1986. Accumulation of biogenic silica and opal dissolution in upper Quaternary Skagerrak sediments. Geo-Mar. Lett., 6: 165-172.

Hurd, D., and Theyer, F., 1977. Changes in the physical and chemical properties of biogenic silica from the central equatorial Pacific. Part II, Refraction index, density, and water content of acid cleaned samples. Am. J. Sci., 277:1168-1202.

Koopmann, B., 1979. Sedimentation von Saharastaub im subtropischen Nordatlantik während der letzten 25,000 Jahre. "Meteor" Forsch. Ergebn., C35:23-59.

Leinen, M., 1977. A normative calculation technique for determining opal in deep-sea sediments. Geochim. Cosmochim. Acta, 41:671676.

Mann, U., and Müller, G., 1980. Composition of sediments of the Japan Trench transect, Legs 56 and 57, Deep Sea Drilling Project. In Langseth, M., Okada, H., et al., Init. Repts. DSDP, 56: Washington (U.S. Govt. Printing Office), 939-977.

Mayer, L., 1979. Deep-sea carbonates: acoustic, physical, and stratigraphic properties. J. Sed. Petrol., 49:819-836.

Sclater, J. G., Hellinger, S., and Tapscott, C., 1977. The paleobathymetry of the Atlantic Ocean from the Jurassic to the Present. J. Geol., 85:509-552.

Stein, R., 1985. The post-Eocene sediment record at DSDP Site 366: Its implications for African climate and plate tectonic drift. In Kennett, J. (Ed.), The Miocene Ocean: Paleoceanography and Biogeography: Geol. Soc. Am. Mem., 163:305-315. 


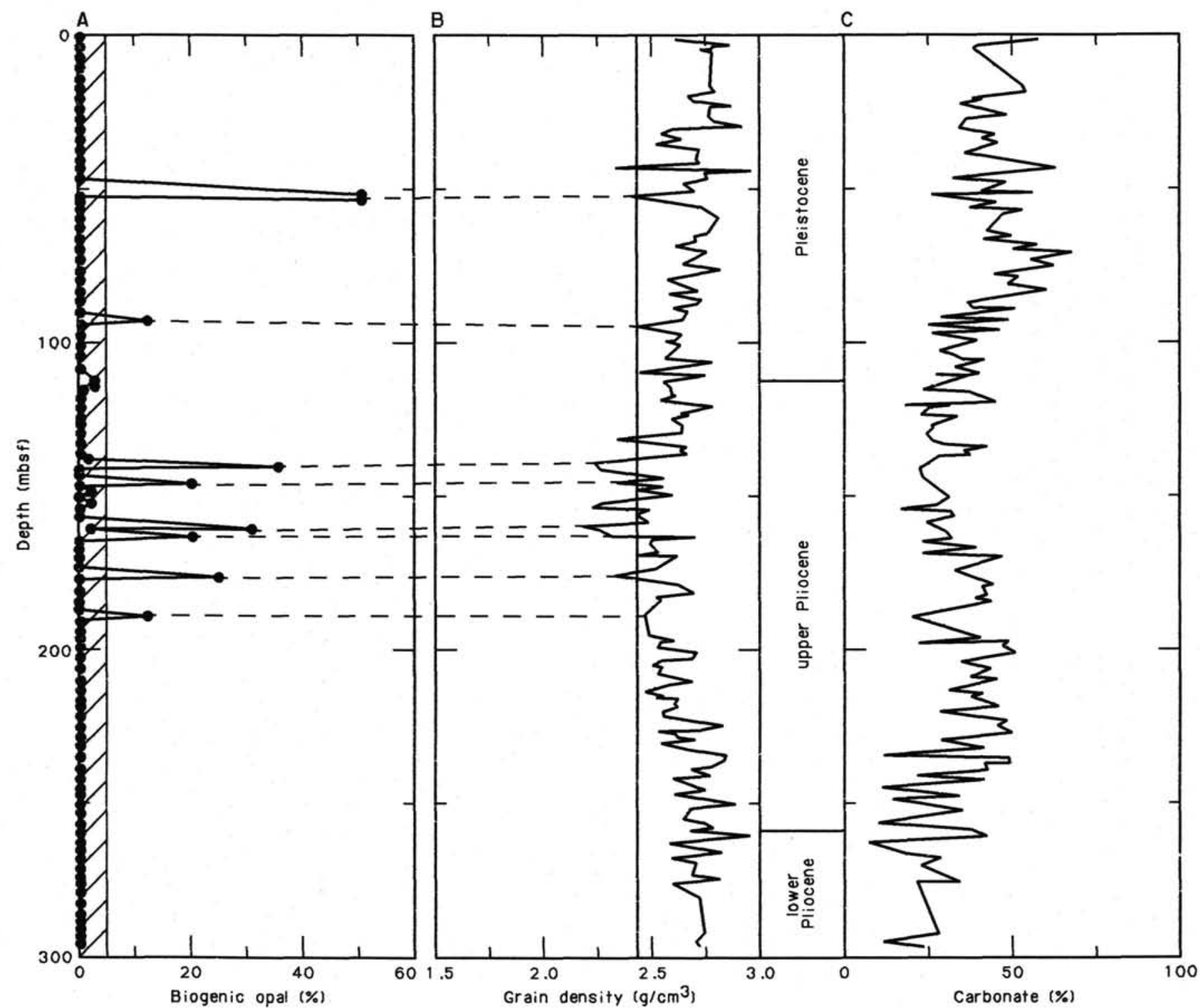

Figure 4. A. Biogenic-opal content at Site 658, based on XRD data. Hatched area indicates biogenic-opal content of less than $10 \%$. B. Grain-density values $\left(\mathrm{g} / \mathrm{cm}^{3}\right)$ at Site 658 . C. Carbonate content at Site 658 . 


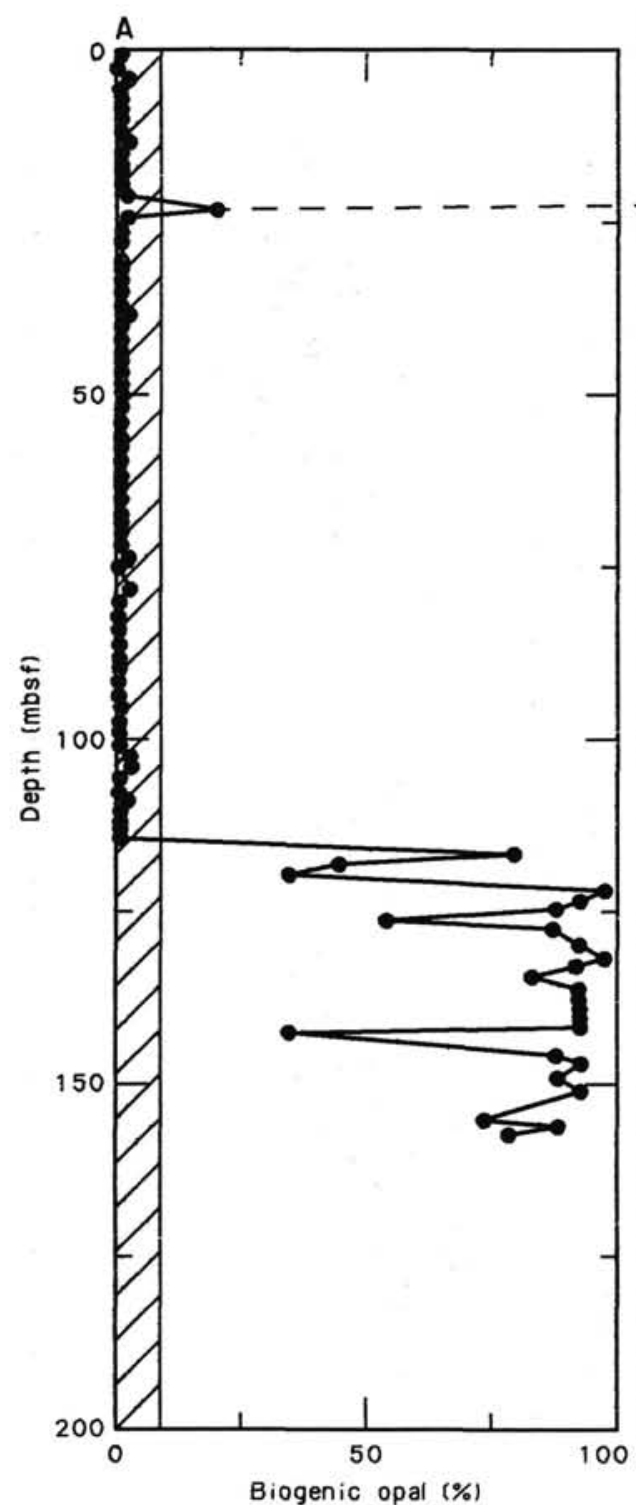

B

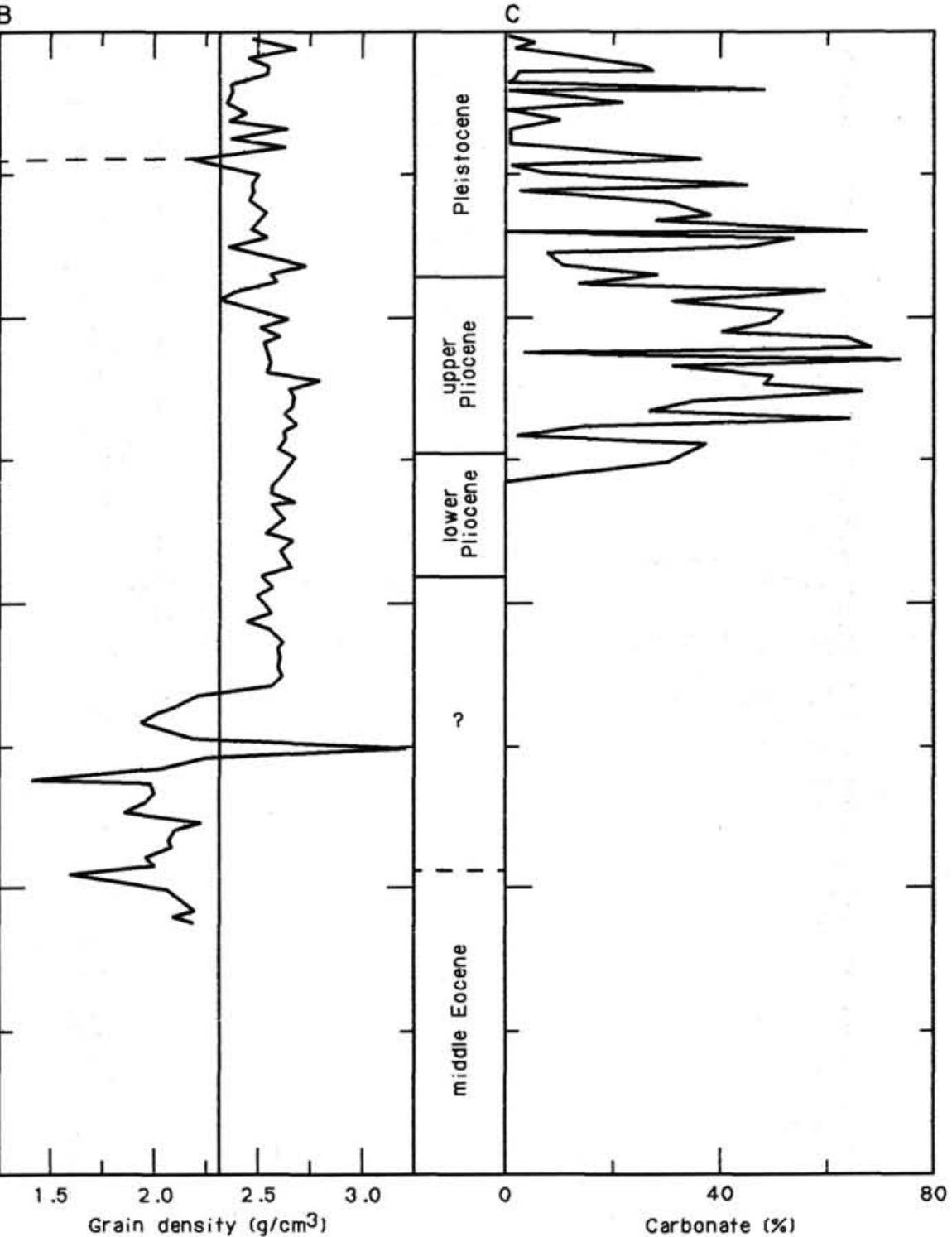

Figure 5. A. Biogenic-opal content at Site 660 , based on XRD data. Hatched area indicates biogenic-opal content of less than $10 \%$. B. Grain-density values $\left(\mathrm{g} / \mathrm{cm}^{3}\right)$ at Site 660 . C. Carbonate content at Site 660 . 


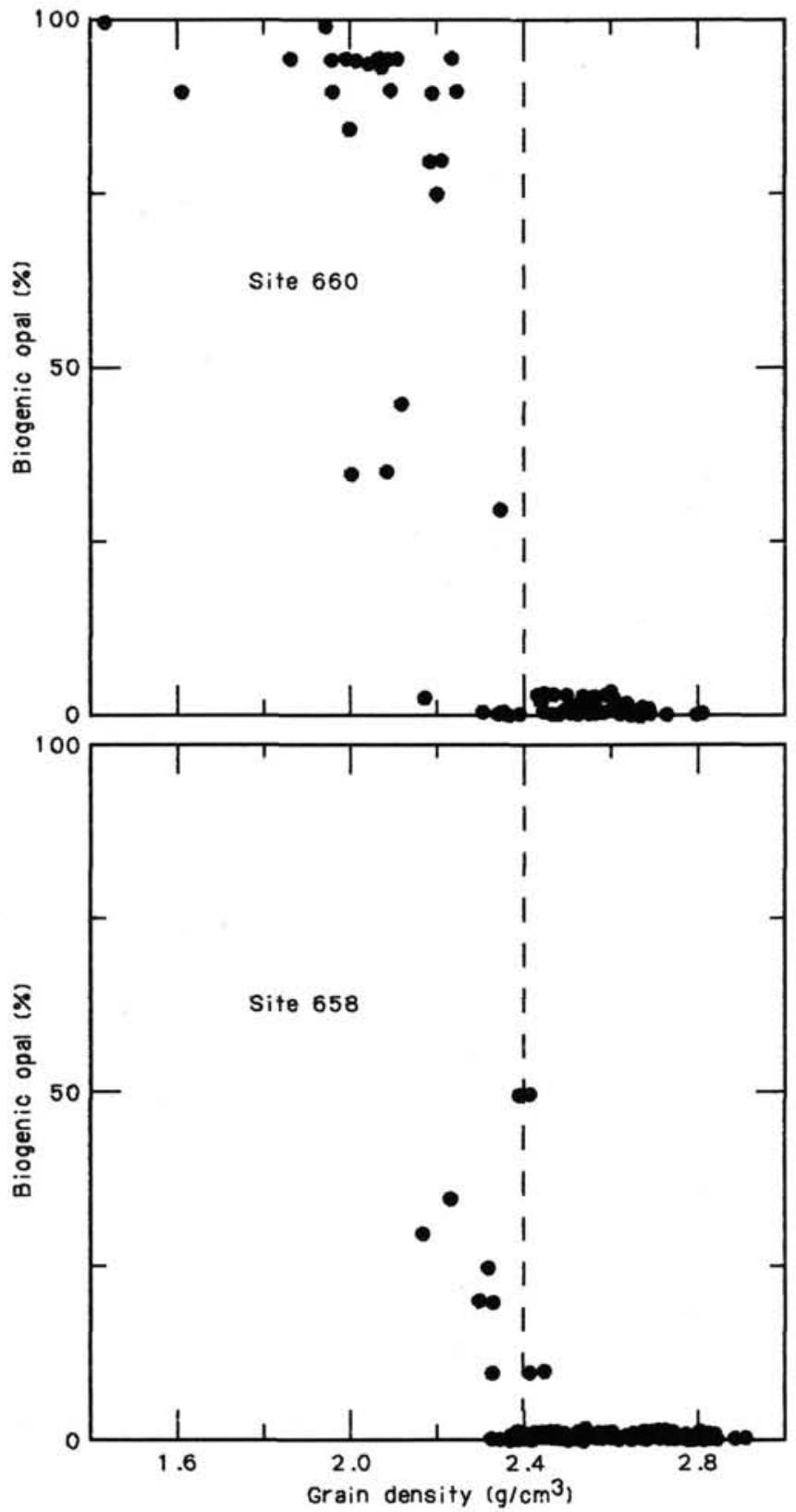

Figure 6. Correlation between biogenic-opal content and grain density, Sites 658 and 660 . 